\title{
Arbeidsrelatert astma - diagnostikk og oppfølging
}

\begin{abstract}
BAKGRUNN 10-15\% av alle astmatilfeller som oppstår hos voksne kan tilskrives eksponering på arbeidet. Arbeidsrelatert astma omfatter både forverring av tidligere astma samt arbeidsbetinget astma hvor eksponering på arbeidsplassen er årsaken til sykdommen. Vel 350 forskjellige eksponeringer er kjent som årsaker til allergisk arbeidsrelatert astma. Hensikten med denne artikkelen er å presentere en oppdatert gjennomgang av diagnostikk og oppfølging ved arbeidsrelatert astma.
\end{abstract}

KUNNSKAPSGRUNNLAG I tillegg til egne søk i PubMed og omfattende klinisk erfaring med denne pasientgruppen bygger artikkelen på flere systematiske litteraturgjennomganger som er foretatt internasjonalt.

RESULTATER Tidlig diagnose krever at legen er oppmerksom på at det kan være arbeidsutløst astma. Primærlegene spiller en viktig rolle for raskt igangsatt diagnostikk. Videre utredning krever ressurser som bare er tilgjengelige ved avdelinger med spesiell kompetanse innen dette feltet. Det er vist at bevissthet om tilstanden og tidlig og korrekt diagnose som fører til opphør av eksponeringen kan bedre prognosen.

FORTOLKNING Alle leger som har ansvar for astmapasienter, må være oppmerksomme på tilstanden og sørge for adekvat diagnostikk slik at intervensjon mot eksponeringen kan gjennomføres. Samarbeid mellom fastlege, arbeidsgiver, bedriftshelsetjeneste og spesialister er nødvendig for å få dette til.

Astma er en utbredt sykdom som kan ramme alle aldersgrupper. I befolkningsundersøkelser synes allergi å være årsak til omkring halvdelen av astmatilfellene (1). Astma som oppstår i voksen alder, kan tilskrives eksponering i arbeid i ca. $10-15 \%$ av tilfellene og er i dag den hyppigste arbeidsbetingede lungesykdom i vestlige land (2).

Nye astmatilfeller som skyldes eksponering $\mathrm{i}$ arbeidet, kan i prinsippet forebygges. Prognosen kan bedres vesentlig når den aktuelle eksponeringen opphører (3). Økt oppmerksomhet omkring tilstanden hos norske leger er nødvendig for å bedre prognosen hos denne gruppen. Tilstanden har tidligere vært omtalt i Tidsskriftet $(4,5)$, men det er nå behov for en oppdatering i lys av nyere forskning.

\section{Kunnskapsgrunnlag}

Artikkelen bygger på forfatternes egne søk i PubMed og omfattende klinisk erfaring med denne pasientgruppen. Søk med kombinasjon av søkeordene «asthma», «occupational diseases», «diagnosis», «diagnostic techniques, respiratory system», «humans» og «adult» ble benyttet. Søket ble avsluttet i september 2013.

I tillegg bygger artikkelen på flere systematiske litteraturgjennomganger som er foretatt internasjonalt, bl.a. av en arbeidsgruppe i European Respiratory Society (ERS) (6-8). Den ene av forfatterne (TBAa) deltok i dette arbeidet.

\section{Definisjon og inndeling av arbeidsrelatert astma}

Arbeidsrelatert astma er astma som er forårsaket av eller forverret av eksponering $i$ arbeid. En praktisk inndeling er nylig introdusert av European Respiratory Society (fig 1) (8):

- Arbeidsforverret astma er astma som forverres av faktorer i arbeidet, slik som irritanter

- Arbeidsbetinget astma er astma hos voksne oppstått på grunn av sensibiliserende substanser (allergisk arbeidsrelatert astma) eller gjennom ikke-immunologiske mekanismer (irritantastma). I enkelte tilfeller foreligger det klinisk klare holdepunkter for sensibilisering, men mekanismen er ukjent og virker uavhengig av eller i tillegg til reaksjon via $\operatorname{IgE}(8)$

\section{Allergisk arbeidsrelatert astma}

Allergi defineres som en overfølsomhetsreaksjon som skyldes spesifikke immunologiske mekanismer. Denne overfølsomheten viser seg ved objektivt reproduserbare symptomer eller funn utløst ved eksponering for en definert stimulus i en styrke som tolereres av normale personer (9).

I dag kjenner man mer enn 350 substanser eller eksponeringer som kan forårsake astma gjennom sannsynlig allergiske mekanismer (tab 1) (10). En uttømmende liste er også tilgjengelig på nettstedet til La Commission de la santé et de la sécurité du travail du Québec (CSST) (11). Agenser som forårsaker aller-
Tor Olav Brøvig Aasen

tor.olav.brovig.aasen@helse-bergen.no

Yrkesmedisinsk avdeling

Haukeland universitetssykehus

\section{Johny Kongerud}

Lungemedisinsk avdeling

Oslo universitetssykehus, Rikshospitalet

Kunnskapsprøve

på www.tidsskriftet.no/quiz

> Se lederartikkel side 1916

\section{HOVEDBUDSKAP}

Eksponering i arbeid er viktig årsak til astma hos voksne og kan være en forverrende faktor hos pasienter med allerede etablert astma

Tidlig diagnose og intervensjon gjør det mulig å få bedring eller restitusjon, i motsetning til når eksponeringen fortsetter etter symptomdebuten

Påvisning av ett tilfelle av astma forårsaket av sensibiliserende stoffer bør føre til omfattende primærforebyggende tiltak for å forhindre nye tilfeller 




Figur 1 Praktisk inndeling av arbeidsrelatert astma (8)

gisk arbeidsrelatert astma kan inndeles i komplette allergener (særlig proteiner) eller lavmolekylære kjemiske stoffer $(<10 \mathrm{kD})$. De sistnevnte antas å fungere som haptener eller virker ved å indusere nye epitoper ved endring av proteiners konformasjon.

Tabell 1 Eksponering for astmafremkallende stoffer i noen yrker og bransjer

\begin{tabular}{|c|c|}
\hline Virksomhet & Eksponering \\
\hline Aluminiumsindustri & Fluorforbindelser i elektrolysehaller \\
\hline Bakerier og møller & $\begin{array}{l}\text { Mel (spesielt hvete), tilsetningsstoffer (a-amylase), sopp, } \\
\text { lagermidd }\end{array}$ \\
\hline Bygningsrelatert & $\begin{array}{l}\text { Opphold i bygninger med fuktskade og eksponering for sopp- } \\
\text { sporer, mykotoksiner og andre emisjoner }\end{array}$ \\
\hline Elektronisk industri & Kolofonium, akrylater, isocyanater \\
\hline Frisørsalonger & Blekemidler, permanent (hovedsakelig irritanter) \\
\hline Helsevesen & Naturgummilateks i hansker, desinfeksjonsmidler (glutaraldehyd) \\
\hline Jordbruk & $\begin{array}{l}\text { Organiske allergener, bl.a. dyr, pollen, sopp, midd og diverse } \\
\text { irritanter }\end{array}$ \\
\hline Laboratorier & Forsøksdyr, spesielt rotter og mus \\
\hline Overflatebehandling & Herdere, spesielt isocyanater og aminer) \\
\hline Plastindustri & Isocyanater, formaldehyd \\
\hline Renhold & En rekke irritanter \\
\hline Tannhelse & Metakrylater, lateks, kolofonium \\
\hline Trevareindustri & Støv fra eksotiske tresorter (western red cedar), lim, formaldehyd \\
\hline Tunnelarbeid & Tetningsmidler (isocyanater), støv og andre irritanter \\
\hline Verkstedindustri & Krom, nikkel, isocyanater \\
\hline $\begin{array}{l}\text { Annen næringsmiddel- } \\
\text { industri }\end{array}$ & $\begin{array}{l}\text { Organiske allergener. Finfordelt støv og damp bl.a. fra mel, soya. } \\
\text { Fisk, skalldyr }\end{array}$ \\
\hline Annen prosessindustri & Ammoniakk, klor, ozon, nitrøse gasser, svovelforbindelser \\
\hline
\end{tabular}

13). Inhalasjon av lokalirriterende gasser eller aerosoler i høye konsentrasjoner kan medføre intens inflammasjon i luftveiene, såkalt irritantastma eller reaktivt luftveisdysfunksjonssyndrom (reactive airway dysfunction syndrome, RADS) (14).

Tragediene i World Trade Center 11.9. 2001 og i Bhopal i 1984 er velkjente eksempler på alvorlige ulykker med store utslipp av lokalirriterende stoffer. Både arbeidstakerne og befolkningen ble rammet, og én av konsekvensene var irritantastma. Gjentatte lavgradige eksponeringer for lokalirriterende substanser (i elektrolysehaller i aluminiuminsdustrien, $\mathrm{i}$ papirindustrien og via vaskemidler hos renholdere) (14) er også mulige årsaker til astma.

\section{Diagnostikk ved allergisk \\ arbeidsrelatert astma}

I alle tilfeller av nyoppstått astma bør legen overveie om sykdommen kan skyldes faktorer i arbeidet. Et viktig kontrollspørsmål er om pasientens symptomer blir bedre i ferier eller på fritiden. Videre diagnostikk bør legges opp systematisk. Primærlegen legger grunnlaget for en god utredning, spesielt gjelder dette tidlig innhenting av eksponeringsopplysninger og måling av toppstrømshastighet (peak expiratory flow, PEF). Man bør i de aller fleste tilfeller samarbeide med en sykehusavdeling med kompetanse for å få tilstrekkelig nøyaktig diagnostikk ved arbeidsrelatert astma.

\section{Sykehistorie}

Et spørreskjema som klarlegger om det foreligger piping i brystet eller dyspné som bedres når pasienten er borte fra arbeidet, har høy sensitivitet, men begrenset spesifisitet. Det samme gjelder sykehistorie som tas opp av eksperter. Men også her er andelen falskt positive betydelig (15).

\section{Eksponeringsvurdering}

En generell arbeidsanamnese omfatter en fortløpende opplisting av skolegang og angivelse av alle arbeidsforhold, med yrkestittel og arbeidsgiver. I den spesielle arbeidsanamnesen forsøker man å beskrive eksponeringer, arbeidsprosesser og verneforhold detaljert. Ved innhenting av produktdatablad og supplerende eksponeringsopplysninger fra bedriften kan man få nærmere informasjon.

Spirometri og bronkial reaktivitetsundersøkelse. Spirometri bør utføres i alle tilfeller. Ved redusert forsert respiratorisk volum etter ett sekund $\left(\mathrm{FEV}_{1}\right)$ kan reversibilitet etter bronkodilatator bekrefte astmadiagnosen. Ved normal spirometri er det indisert å foreta undersøkelse av bronkial reaktivitet med metakolin. Økt uspesifikk bronkial reaktivitet finnes hos de fleste pasienter med aktiv astma. Det er imidlertid kommet en 
rekke rapporter som viser at denne kan forsvinne raskt etter opphør av eksponering (16). Negativ metakolintest utelukker derfor ikke arbeidsrelatert astma i slike situasjoner.

\section{Undersøkelse av lungefunksjon \\ $i$ arbeid og fritid}

Måling av toppstrømshastigheten skjer med et enkelt apparat eller med et håndholdt spirometer og kan dokumentere bronkokonstriksjon under eller etter arbeid. Det kan dermed påvises en samvariasjon mellom eksponering $i$ arbeidet og redusert luftstrømshastighet.

For å få en adekvat undersøkelse anbefales at målingen gjennomføres minst fire ganger daglig (eller bedre hver 2. time så lenge pasienten er våken) (fig 2) (16). Tre ukers registrering med tre perioder borte fra arbeid (f.eks. helger) vil være nok for en analyse av sammenhengen mellom eksponering og lungefunksjon (17).

OASYS er program for analyse av PEFregistreringer som er fritt tilgjengelig på nettet $(18,19)$. I en systematisk oversikt ble den gjennomsnittlige sensitiviteten og spesifisiteten for arbeidsrelatert astma ved gjentatte PEF-målinger beregnet til henholdsvis $82 \%$ og $88 \%$ (20). Undersøkelsen må utføres mens pasienten ennå er i arbeid. Ved feil teknisk utførelse og registrering av data kan man få misvisende resultater. Forfalskning kan forekomme, men kan begrenses ved bruk av datalogger (17). Foreløpig er erfaringen med håndholdte spirometre begrenset. Disse krever enda bedre kontroll med den tekniske utførelsen.

\section{Allergologiske undersøkelser}

Prikktest og måling av spesifikt IgE mot luftveisallergener $\mathrm{i}$ yrket er tilgjengelig i begrenset utstrekning. Prikktest angis å være noe mer sensitiv, men mindre spesifikk enn IgE-måling (21). Prikktest bør utføres i henhold til internasjonale retningslinjer (22). Prikktest mot lavmolekylære allergener er i praksis ikke tilgjengelig. Ekstrakter av yrkesallergener er i liten grad standardiserte og må tillages på stedet, noe som forutsetter tilgjengelige biologiske kontrollpersoner (normalpersoner).

Isocyanater er meget utbredte herdere $\mathrm{i}$ plast- og lakkprodukter. Siden IgE overfor enkelte isocyanater bare kan påvises hos en mindre andel av pasienter med isocyanatbetinget astma, kan en negativ test ikke utelukke diagnosen (23). Histaminfrigjøringstest og basofil aktiveringstest er nyere undersøkelser som muliggjør påvisning av spesifikt $\operatorname{IgE}$ bundet til basofile granulocytter.

\section{Måling av inflammasjonsmarkører}

In vivo-måling av inflammatorisk aktivitet har fått økt interesse de senere år. Eosinofile granulocytter synes å være dominerende



Toppstrømshastighet (PEF), l/min

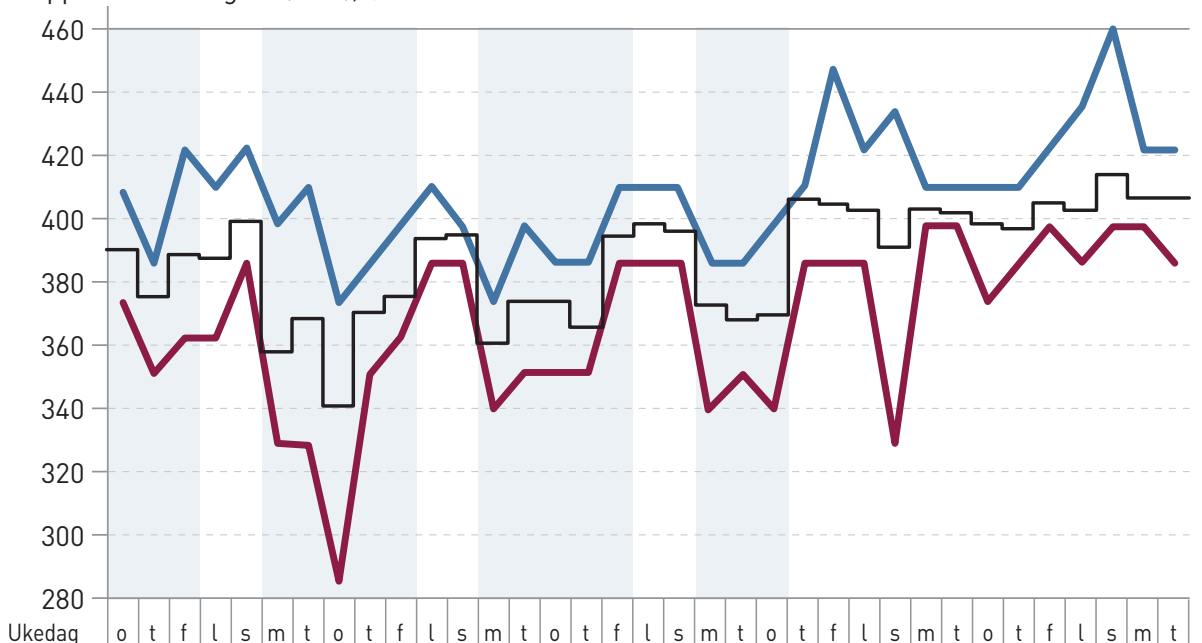

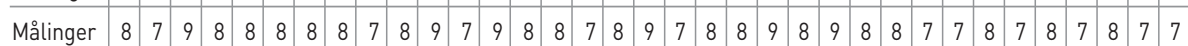

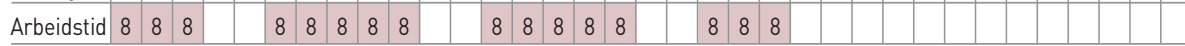

Daglig maksimum Daglig gjennomsnitt Daglig minimum

$\square$ Pasienten var borte fra arbeid $\square$ Pasienten var på arbeid $\square$ Eksponert for isocyanater

Figur 2 PEF-registrering hos pasient som var eksponert for isocyanater. Her er markert høyeste, laveste og middelverdi for hver dag samt døgnvariasjon. Øverst er angitt døgnvariasjonen i prosent. Dager i arbeid er skravert. Registreringen taler for at det er en sammenheng mellom eksponering i arbeidet og PEF-variasjon. PEF-data er analysert med OASYS-programmet (16)

effektorceller ved astmatisk inflammasjon. Indusert sputum ved inhalasjon av hypertont saltvann kan analyseres med henblikk på cellefordeling og mediatorer.

Prosentandel eosinofile celler i sputum er et godt mål for eosinofil inflammasjon i luftveiene (24). Ved arbeidsrelatert astma har imidlertid mange pasienter med astma forårsaket av lavmolekylære kjemiske stoffer økt andel nøytrofile celler. Det er en pågående diskusjon om nøytrofil astma er en egen fenotype (25).

\section{Spesifikk inhalasjonsprovokasjon (SIP)}

Dette er referansemetoden ved diagnostikk av allergisk arbeidsrelatert astma. Pasienten blir eksponert under kontrollerte betingelser for det mistenkte allergenet eller kjemiske stoffet. Reaksjonen avleses som fall i FEV ${ }_{1}$, øning av bronkial reaktivitet eller økt inflammatorisk reaksjon. Metoden er ikke ny i Norge, men krever spesiell ekspertise og utstyr. De aktuelle stoffene (støv eller damp) kan enten tilføres ved å reprodusere den aktuelle arbeidsoperasjonen hvor det mistenkte stoffet forekommer eller via spesiell apparatur (26).
Metoden er ressurskrevende og er foreløpig tilgjengelig ved Yrkesmedisinsk avdeling, Haukeland universitetssykehus. Metoden har nylig vært grundig gjennomgått av en arbeidsgruppe nedsatt av European Respiratory Society, som har publisert sine anbefalinger (27).

\section{Diagnostikk ved irritantastma}

Irritantastma diagnostiseres ut fra opplysninger om kjemikalieulykker eller utslipp av irriterende gasser eller aerosoler. Velkjente eksempler er klorgass, ammoniakk eller eddiksyre. Diagnosen kan stilles ut fra kriterier som omfatter opptreden av astma innen 24 timer etter inhalasjon av lokalirriterende stoffer i høy konsentrasjon hos tidligere lungefriske (ramme 1) (14).

Diagnostisering av astma som skyldes sannsynlig lavgradig irritanteksponering er aktuelt i noen situasjoner. Dette foreligger hvor astma har oppstått i et miljø med eksponering for irritanter som er mistenkt for å indusere sykdommen. Et eksempel på dette er «hallastma» i aluminiumsindustrien. Det foreligger foreløpig ikke etablerte diagnostiske kriterier ved denne tilstanden. 


\section{RAMME 1}

Diagnostiske kriterier ved irritantastma (reactive airway dysfunction syndrome, RADS).

- Dokumentert fravær av lungesymptomer før hendelsen

- Symptomdebut etter en enkeltstående hendelse eller ulykke

- Eksponering for svært høy konsentrasjon av lokalirriterende gass eller røyk

- Start av symptomer innen 24 timer etter ulykken med varighet minst tre måneder

- Tilstedeværelse av astmaliknende symptomer: hoste, piping i brystet, dyspné

- Påvist luftveisobstruksjon ved lungefunksjonsundersøkelse (første undersøkelse bør utføres umiddelbart etter hendelsen)

- Påvist økt bronkial reaktivitet

- Andre lungesykdommer må være utelukket

\section{Risikofaktorer}

Eksponering for sensibiliserende stoffer er den dominerende risikofaktor for arbeidsbetinget astma (28). Disse stoffene har forskjellig allergen potens, noe som har betydning for astmarisikoen.

Atopi er en kjent risikofaktor for allergisk arbeidsrelatert astma, men bare for høymolekylære allergener, hovedsakelig proteiner. Betydning av røyking for utvikling av tilstanden er uavklart. Forskjellige HLA-typer har vært assosiert med variasjon i sensibiliseringsrisiko for enkelte agenser, men foreløpig synes disse funnene å ha begrenset praktisk betydning. Forskjellige typer av studier har vist variasjon i forekomst av arbeidsrelatert astma.

Forebygging kan oppnås ved kontroll med forekomsten av astmafremkallende stoffer på arbeidsstedet. Ved at nye tilfeller av astma blir raskt identifisert og tatt hånd om, kan man forhindre at sykdommen blir kronisk. Populasjonsstudier kan gi verdifull informasjon, men innebærer risiko for feilklassifisering av eksponering og sykdomsdiagnose. Det er i slike studier spesielt problematisk å differensiere mellom forskjellige undergrupper, slik som arbeidsforverret versus arbeidsbetinget astma.

\section{Tiltak og oppfølging}

Arbeidsrelatert astma bør mistenkes i alle tilfeller hvor det foreligger nyoppstått astma i voksen alder. Diagnosen og derav følgende tiltak bør skje med minst mulig forsinkelse, ettersom muligheten for remisjon avtar etter 6-12 måneder etter symptomstart (29). Kanskje er det ikke nok oppmerksomhet om dette i Norge (5)?
Man bør undersøke om det foreligger eksponering for sensibiliserende stoffer og irritanter på arbeidsstedet og om det er flere enn indekspasienten som har liknende symptomer. PEF-registrering bør igangsettes så raskt som mulig, det vil si mens pasienten fortsatt er eksponert.

Påvisning av sensibiliserende stoffer som årsak til arbeidsrelatert astma bør lede til opphør av eksponering straks diagnosen er sikret Eksponeringen kan stoppes ved yrkeshygieniske tiltak - ved at det mistenkte stoffet erstattes (substitusjon) eller ved innkapsling av produksjonsprosessen. Dersom dette ikke er mulig, er alternativene omplassering på bedriften eller skifte av arbeidssted. Videre eksponering må overvåkes nøye, spesielt kan videre eksponering for irritanter gi et vedvarende problem selv om den opprinnelige årsaken er fjernet. Medikamentell terapi styres etter generelle retningslinjer for astmabehandling (30).

Et nytt tilfelle av allergisk arbeidsrelatert astma $i$ en bedrift bør betraktes son en signalhendelse (sentinel event) (31). Dette medfører at pasientens arbeidskamerater og andre i samme bransje kan ha økt risiko for sensibilisering dersom ikke forebyggende tiltak iverksettes. Arbeidsmiljøet bør optimaliseres og videre eksponering overvåkes.

Der hvor eksponering for det sensibiliserende stoffet ikke kan forhindres helt, bør arbeidsmiljø og arbeidstakere overvåkes videre. Ved noen sensibiliserende stoffer hvor det kan forekomme et symptomfritt intervall hos sensibiliserte, kan prikktest eller spesifikk IgE-måling brukes for å påvise sensibilisering. Dette muliggjør igangsetting av sekundær forebygging. Dette har vi foreløpig få eksempler på. Det har vært påvist høy risiko for sensibilisering mot enzymer innen vaskemiddelproduksjon og mot platinasalter i kjemisk industri (10). I de fleste tilfeller er imidlertid overvåking med henblikk på sensibilisering ikke praktisk mulig. I slike tilfeller gir økt oppmerksomhet og tidlig diagnose gode muligheter for å bedre prognosen. Siden risikoen for sensibilisering er høyest de to første år etter ansettelse, er dette et bra rasjonale for spørreskjemaundersøkelse supplert med lungefunksjonsmåling hver 3.-6. måned i denne perioden. Intervallet kan deretter økes, til for eksempel $1-2$ år (32).

\section{Prognose ved arbeidsrelatert astma}

I en systematisk litteraturoversikt ble det konkludert med at $32 \%$ av pasientene i kohorter som var fulgt i 32 måneder etter opphør av eksponering, fikk klinisk remisjon (3). Uspesifikk økning av bronkial reaktivitet vedvarte hos $73 \%$, men bedring i reaktivitet kan ses i løpet av de første 24 månedene etter opphør av eksponering. Eks- poneringstiden etter at astmasymptomene er oppstått ser ut til å være den mest dominerende prognostiske faktor (8).

For de fleste av disse pasientene resulterer diagnosen arbeidsrelatert astma i et betydelig økonomisk tap (33). Dagens norske regelverk garanterer heller ikke at pasienten kan opprettholde sin inntekt, og vi har sett mange eksempler på at disse havner i økonomisk uføre (34). Et regelverk tilpasset disse forhold samt raskere saksbehandling vil kunne bøte på dette.

\section{Konklusjon}

Nyoppstått astma hos voksne kan skyldes eksponering på arbeidet hos 10-15\%. Legene bør være seg denne muligheten bevisst. «Bedres symptomene når du er borte fra arbeidet?» er et spørsmål med høy sensitivitet. Positivt svar bør føre til videre diagnostiske tiltak for å få en sikker diagnose. Påvisning av ett enkelt tilfelle av allergisk arbeidsrelatert astma på en arbeidsplass bør føre til videre undersøkelse om det kan være flere rammede og lede til adekvate forebyggende tiltak. Der hvor sensibiliserende stoffer ikke helt kan elimineres (f.eks. i bakerier), bør helseovervåking institueres for å kunne påvise astma i tidlig fase for slik å forhindre videre utvikling av sykdommen.

Det er behov for bedre diagnostikk og oppfølging av disse pasientene. Dette må også omfatte hjelp til sikring av økonomiske rettigheter og tilrettelegging av fremtidige arbeidsmuligheter

\section{Tor Olav Brøvig Olsen (f. 1946)}

er spesialist i lungesykdommer og $\mathrm{i}$ indremedisin, med spesiell kompetanse innen arbeidsrelaterte lungesykdommer. Han er tidligere avdelingsoverlege og avdelingsdirektør, nå spesialrådgiver/pensjonist.

Forfatter har fylt ut ICMJE-skjemaet og oppgir ingen interessekonflikter.

\section{Johny Kongerud (f. 1949)}

er spesialist i indremedisin og i lungesykdommer og avdelingsoverlege.

Forfatter har fylt ut ICMJE-skjemaet og oppgir ingen interessekonflikter.

Litteratur

1. Pearce N, Douwes J, Beasley R. Is allergen exposure the major primary cause of asthma? Thorax 2000; 55: 424-31.

2. Blanc PD, Toren K. How much adult asthma can be attributed to occupational factors? Am J Med 1999: 107: $580-7$

3. Rachiotis G, Savani R, Brant A et al. Outcome of occupational asthma after cessation of exposure a systematic review. Thorax 2007; 62: 147-52.

Kongerud J, Naalsund A. Yrkesrelatert astma. Forekomst, diagnostikk, forløp og forebyggelse. Tidsskr Nor Lægeforen 1992; 112: 892-6. 
5. Leira HL. Astma i norsk arbeidsliv. Tidsskr Nor Legeforen 2008; 128: 2719-21.

6. Beach J, Rowe BH, Blitz S et al. Diagnosis and management of work-related asthma. Rockville, MD: Agency for Healthcare Research and Quality, 2005.

7. Nicholson PJ, Cullinan P. Burge PS et al. Occupational asthma: prevention, identification \& management: systematic review \& recommendations. London: British Occupational Health Research Foundation, 2010

8. Baur X, Sigsgaard T, Aasen TB et al. Guidelines for the management of work-related asthma. Eur Respir J 2012; 39: 529-45.

9. Johansson SG, Bieber T, Dahl R et al. Revised nomenclature for allergy for global use: Report of the Nomenclature Review Committee of the World Allergy Organization, October 2003. J Allergy Clin Immunol 2004; 113: 832-6.

10. Baur X, Bakehe P. Allergens causing occupational asthma: an evidence-based evaluation of the literature. Int Arch Occup Environ Health 2014; 87: $339-63$.

11. La Commission de la santé et de la sécurité du travail du Québec (CSST). Asthme professionnel. www.asthme.csst.qc.ca (28.3.2014)

12. Tarlo SM. Workplace irritant exposures: do they produce true occupational asthma? Ann Allergy Asthma Immunol 2003; 90 (suppl 2): 19-23.

13. Gautrin D, Bernstein IL, Brooks SM et al. Reactive airways dysfunction syndrome and irritant-induced asthma. I: Bernstein IL, Chan-Yeung M, red. Asthma in the Workplace. 3. utg. New York: Taylor \& Francis, 2006: 581-629.

14. Brooks SM, Weiss MA, Bernstein IL Reactive airways dysfunction syndrome (RADS). Persistent asthma syndrome after high level irritant exposures. Chest 1985; 88: 376-84

15. Malo JL, Ghezzo H, L'Archevêque J et al. Is the clinical history a satisfactory means of diagnosing occupational asthma? Am Rev Respir Dis 1991; 143: 528-32.

16. Aasen TB, Burge PS, Henneberger PK et a. Diagnostic approach in cases with suspected workrelated asthma. J Occup Med Toxicol 2013; 8: 17

17. Moscato G, Godnic-Cvar J, Maestrelli P. Statement on self-monitoring of peak expiratory flows in the investigation of occupational asthma. J Allergy Clin Immunol 1995; 96: 295-301.

18. The Oasys Computer Program. www.occupationalasthma.com/oasys.aspx (28.3.2014).

19. Gannon PF, Newton DT, Belcher J et al. Development of OASYS-2: a system for the analysis of serial measurement of peak expiratory flow in workers with suspected occupational asthma. Thorax 1996; 51: 484-9.

20. Moore VC, Jaakkola MC, Burge PS. A systematic review of serial peak expiratory flow measurements in the diagnosis of occupational asthma. Annals of Respiratory Medicine 2009; 1: 31-44.

21. Quirce S. IgE antibodies in occupational asthma: are they causative or an associated phenomenon? Curr Opin Allergy Clin Immunol 2014; 14: 100-5.

22. Dreborg S, Frew A. Allergen standardization and skin tests. Allergy 1993; 48 (suppl 14): 49-54.

23. Tee RD, Cullinan P. Welch J et al. Specific IgE to socyanates: a useful diagnostic role in occupational asthma. J Allergy Clin Immunol 1998; 101: 709-15.

24. Djukanovic R, Sterk PJ, Fahy JV et al. Standardized methodology of sputum induction and processing. Eur Respir J 2002; 20 (suppl 37): 1-55.
25. Gibson PG. Inflammatory phenotypes in adult asthma: clinical applications. Clin Respir J 2009; 3: $198-206$

26. Vandenplas O, Malo JL. Inhalation challenges with agents causing occupational asthma. Eur Respir J 1997; 10: 2612-29.

27. Vandenplas O, Suojalehto H, Aasen TB et al. Specific inhalation challenge in the diagnosis of occupational asthma: consensus statement. Eur Respir J 2014; 43: 1573-87.

28. Vandenplas 0. Occupational asthma: etiologies and risk factors. Allergy Asthma Immunol Res 2011; 3: 157-67.

29. Maestrelli P, Schlünssen V, Mason P et al. Contribution of host factors and workplace exposure to the outcome of occupational asthma. Eur Respir Rev 2012; 21: 88-96.

30. Vandenplas 0 , Dressel H, Nowak D et al. What is the optimal management option for occupational asthma? Eur Respir Rev 2012; 21: 97-104.

31. Matte TD, Hoffman RE, Rosenman KD et al. Surveillance of occupational asthma under the SENSOR model. Chest 1990; 98 (suppl): 173S-8S

32. Wilken D, Baur $X$, Barbinova $L$ et al. What are the benefits of medical screening and surveillance? Eur Respir Rev 2012; 21: 105-11.

33. Burge PS. Who bears the costs of occupational asthma? Thorax 2011; 66: 92-3

34. Wergeland E. I strid med arbeidervernloven. Dagens Medisin 2011. www. dagensmedisin.no/ debatt/i-strid-med-arbeidervernloven/ (28.3.2014).

Mottatt 20.9. 2013, første revisjon innsendt 28.1. 2014, godkjent 28.3. 2014. Redaktør: Sigurd Høye. 